\title{
KEBUTUHAN PERAWATAN PERIODONTAL PADA ANAK BERKEBUTUHAN KHUSUS
}

\author{
*Desi Andiyani \\ *Jurusan Keperawatan Gigi Poltekkes Tanjungkarang
}

\begin{abstract}
Penyebab utama penyakit periodontal adalah iritasi bakteri plak. Lapisan ini terbentuk dan melekat erat pada permukaan gigi bila seseorang mengabaikan kebersihan gigi dan mulutnya. Pembentukan plak gigi dipengaruhi oleh faktor predisposisi yang terdapat secara lokal pada lingkungan rongga mulut atau standar PH dimana kalkulus yang mempengaruhi kalsifikasi dari plak gigi berhubungan dengan lepasnya perlekatan periodontal pada individu dengan oral hygiene yang rendah. Penelitian ini bertujuan untuk mengetahui kebutuhan perawatan Periodontal pada anak berkebutuhan khusus di SLB Dharma Bakti. Penelitian ini merupakan penelitian observasional dengan jumlah sampel sebanyak 52 anak. Pengambilan data dilakukan dengan pemeriksaan menggunakan kaca mulut dan probe menggunakan CPITN, kemudian daata dicatat pada lembaran pemerikasaan CPITN. Hasil penelitian menunjukan kategori status penyakit periodontal dari 52 anak terdapat kondisi karang gigi 33 anak (63,46\%) dan hasil ini menunjukan kategori kebutuhan perawatan dimana dengan kotegori tersebut harus dilakukan pembersihan karang gigi (scalling) dan pemberian pendidikan tentang kesehatan gigi dan mulut berupa penyuluhan.
\end{abstract}

Kata Kunci: periodontal, anak, berkebutuhan khusus

\section{LATAR BELAKANG}

Gingivitis dan periodontitis adalah dua bentuk utama dari penyakit peradangan yang mempengaruhi periodontium. Etiologiutama mereka adalah plakbakteri, yang dapat memulai penghancuran jaringan gingiva dan perlekatan periodontal. Gingivitis adalah peradangan pada gusi yang tidak mengakibatkan kehilangan perlekatan klinis. Periodontitis adalah peradangan gusi yang ditandai dengan hilangnya perlekatan jaringan ikat dan tulang alveolar. Masing-masing penyakit dapat diklasifikasikan berdasarkan etiologi (Haake, Kinder \& Newman, 2000).

Penyakit periodontal banyak diderita oleh manusia hampir di seluruh dunia dan mencapai $50 \%$ dari jumlah populasi dewasa. Menurut hasil survai kesehatan gigi di Jatim tahun 1995, penyakit periodontal terjadi pada 459 orang diantara 1000 penduduk dan lebih banyak di pedesaan dari pada perkotaan. Di Asia dan Afrika.prevalensi dan intensitas penyakit periodontal terlihat lebih tinggi daripada di Eropa,Amerika dan Australia. Di Indonesia penyakit periodontal menduduki urutan ke dua utama yang masih merupakan masalah di masyarakat (Wahyukundari, 2009).

Penyakit periodontal juga merupakan salah satu penyakit yang sangat meluas dalam kehidupan masyarakat, sehingga mereka menganggap penyakit ini sebagai sesuatu yang tidak terhindari. Seperti karies gigi, penyakit periodontal juga lambat perkembangannya dan apabila tidak dirawat dapat menyebabkan kehilangan gigi.Namun studi epidemiologi menunjukkan bahwa penyakit ini dapat dicegah dengan pembersihan plak dengan sikat gigi dengan teratur serta menghilangkan karang gigi apabila ada. Gingivitis dan periodontitis merupakan penyebab terjadinya penyakit periodontal. Gingivitis adalah peradangan pada gusi dengan tanda-tanda klinis perubahan warna lebih merah dari normal, gusi membengkak, dan berdarah pada tekanan ringan. Biasanya tidak menimbulkan rasa sakit hanya keluhan gusi berdarah bila sikat gigi. Periodontitis biasanya dijumpai pada usia antara 30-40 tahun,perkembangan penyakit ini lambat. Pada periodontitis proses peradangan sudah sampai kejaringan yang lebih dalam dan apabila tidak dirawat maka pada waktu yang lama 
kemudian dapat menyebabkan kehilangan gigi. Penyakit periodontal merupakan penyebab terbesar dari kehilngan gigi pada orang dewasa di usia 30 tahun ke atas. Epidemiologi penyakit periodontal menunjukkan bahwa prevalensi dan keparahan penyakit periodontal dipengaruhi oleh umur, jenis kelamin, faktor lokal rongga mulut, dan faktor sistemik (Axelsson, 2000).

Berdasarkan data Sensus Nasional Biro Statistik (BPS) tahun 2007 jumlah penyandang cacat di Indonesia sebesar $0,7 \%$ dari jumlah penduduk sebesar 211.428 .572 atau sebanyak 1.480 .000 jiwa. Sebagian dari jumlah tersebut $24,45 \%$ atau 361.860 diantaranya adalah anak-anak usia 0-18 tahun dan 21,42\% atau 317.016 anak merupakan anak usia sekolah (5-18 tahun). Sekitar 66.610 anak usia sekolah penyandang cacat $(14,4 \%$ dari seluruh anak penyandang cacat) ini terdaftar di Sekolah Luar Biasa (Kemenkes, 2010).

Menurut organisasi kesehatan dunia (WHO), lebih dari 5\% dari populasi dunia, sekitar 360 juta orang mengalami gangguan pendengaran (328 juta orang dewasa dan 32 juta anak-anak). Prevalensi anak tunarungu di Indonesia berdasarkan data statistik Depertemen Pendidikan Nasional Indonesia menunjukkan bahwa jumlah anak-anak tunarungu di Indonesia cukup tinggi mencapai 0,17\% dimana 17 dari 10.000 anak pra sekolah sampai umur 12 tahun mengalami tuli. Hasil penelitian yang dilakukan di SLBN Purbolinggo didapat nilai kebersihan rata - rata 2,01.

Penelitian yang dilakukan Rukayah tahun 2014 pada siswa tunarungu di SLB Cicendo Bandung, didapatkan data bahwa sebanyak 21 dari 30 responden memiliki kategori OHI-S buruk yaitu sebesar $70 \%$. Hasil pemeriksaan tersebut dipengaruhi oleh keterbatasan fisik pada anak, yang menyebabkan fungsi dan kemampuan mereka dalam memelihara kesehatan gigi yang terbatas. Penelitian Tagelsir dkk menyatakan bahwa penderita tunagrahita kurang memiliki kemampuan dalam memelihara kesehatan rongga mulut karena mereka mengalami kesulitan dalam membuka akses untuk perawatan gigi. Penderita tunagrahita mengalami kesulitan dalam mendeteksi dan mengenali keadaan rongga mulut mereka, sehingga tidak dapat dilakukan penanganan bila terjadi gangguan.

Berdasarkan observasi awal yang peneliti lakukan pada siswa SLB Dharma Bakti yang berjumlah 10 anak menunjukkan bahwa 20\% dengan skor sehat, 30\% dengan skor berdarah dan $50 \%$ dengan skor karang gigi . Data tersebut menunjukkan bahwa anak tunagrahita dan tunarungu memiliki kebersihan gigi dan mulut yang buruk, hal tersebut disebabkan karena belum pernah mendapatkan pendidikan mengenai kebersihan gigi dan mulut dari pihak sekolah dan pelayanan kesehatan setempat untuk memberikan pengetahuan tentang kebersian gigi dan mulut.

\section{METODE}

Penelitian ini bertujuan untuk mengetahui status penyakit periodontal pada anak berkebutuhan khusus dengan desain penelitian observasional. mengetahui kebutuhan perawatan. Sampel pada penelitian ini adalah seluruh siswa SLB Dharma Bakti yang berjumlah 52 responden.

Data penelitian dikumpulkan dengan melakukan pemeriksaan CPITN jaringan periodontal dan kueisiner tentang kebutuhan perawatan periodontal. Selanjutnya data diolah dan dianalisis dengan bantuan komputer. Analisis data dilakukan secara univariat pada seluruh data variabel penelitian. Dalam analisis univariat data dianalisis dan disajikan secara deskriptif dalam bentuk tabel frekuensi dan persentase. 
HASIL

Tabel 1: Distribusi Status Kondisi Jaringan Periodontal pada Anak Berkebutuhan Khusus

\begin{tabular}{lcc}
\hline $\begin{array}{c}\text { Skor kondisi jaringan } \\
\text { periodontal }\end{array}$ & $\mathrm{f}$ & $\%$ \\
\hline Sehat & 18 & 34,61 \\
\hline Perdarahan & 1 & 1,92 \\
\hline Karang gigi & 33 & 63,46 \\
\hline Poket dangkal 4-5 mm & 0 & 0 \\
\hline Poket dalam 6 mm & 0 & 0 \\
\hline \multicolumn{1}{c}{ Jumlah } & 52 & 100 \\
\hline
\end{tabular}

Dari tabel di atas dapat dilihat bahwa dari 52 anak di SLB Dharma Bakti ada 18 $(34,61 \%)$ kondisi sehat, 1 anak $(1,92 \%)$ kondisi perdarahan,kondisi karang gigi 33 $(63,46 \%)$ dan untuk kondisi poket dangkal dan dalam $0 \%$.

Tabel 2: Distribusi Kebutuhan Perawatan Periodontal pada Anak Berkebutuhan Khusus

\begin{tabular}{|l|c|c|}
\hline $\begin{array}{c}\text { Kebutuhan perawatan } \\
\text { periodontal }\end{array}$ & $\mathrm{f}$ & $\%$ \\
\hline Tidak membutuhkan & 18 & 34,61 \\
\hline EIKM & 1 & 1,92 \\
\hline EIKM + SK & 33 & 63,46 \\
\hline EIKM + RP & 0 & 0 \\
\hline EIKM + SK + RP & 0 & 0 \\
\hline \multicolumn{1}{|c|}{ Jumlah } & 52 & 100 \\
\hline
\end{tabular}

Dari tabel di atas dapat dilihat bahwa dari 52 anak di SLB Dharma Bakti ada 18 $(34,61 \%)$ sehat dan tidak membutuhkan perawatan periodontal, 1 anak $(1,92 \%)$ memerlukan edukasi instruksi kesehatan mulut (EIKM), 33 anak $(63,46 \%)$ memerlukan ddukasi instruksi kesehatan mulut (EIKM) dan instruksi skalling (SK), untuk kondisi poket dangkal dan dalam $0 \%$ tidak memerlukan memerlukan edukasi instruksi kesehatan mulut (EIKM), instruksi skalling (SK), root planing (RP).

\section{PEMBAHASAN}

\section{Kondisi Jaringan Periodontal pada Anak Berkebutuhan Khusus}

Hasil penelitan menggambarkan bahwa dari 52 anak berkebutuhan khusus di SLB Dharma Bakti ada karang gigi 33 $(63,46 \%)$. Hal ini mungkin disebabkan karena anak tunagrahita dan tunarungu masih memiliki kesadaran yang kurang untuk memelihara kebersihan dan kesehatan mulutnya sehingga memungkinkan bakteri untuk berkembang secara progresif menjadi plak atau kalkulus yang sangat besar.

Berdasarkan penelitian Tagelsir, dkk menyatakan bahwa penderita tunagrahita dan tunarungu kurang memiliki kemampuan dalam memelihara kesehatan rongga mulut karena mereka mengalami kesulitan dalam membuka akses dan mendengar untuk perawatan gigi. Penderita tunagrahita dan tunarungu mengalami kesulitan dalam mendeteksi dan mengenali keadaan rongga mulut mereka, sehingga tidak dapat dilakukan penanganan bila terjadi gangguan.selain itu juga dikarenakan keterbatasan dalam berpikir dan kecerdasan dibawah rata rata seharusnya mereka selalu diberikan pengetahuan dan bimbingan dalam menjaga kesehatan gigi dan mulutnya.

Berdasarkan informasi yang di dapat dari Kepala Sekolah SLB Dharma Bakti, di sekolah tersebut tidak memiliki UKGS (Usaha Kesehatan Gigi Sekolah), di Sekolah tersebut tidak pernah dilakukan Sikat Gigi Massal (SGM) secara rutin kepada para siswa dan tidak pernah mendapatkan penyuluhan mengenai kesehatan gigi dan mulut. Hal tersebut juga merupakan salah satu faktor yang mempengaruhi kebersihan gigi dan mulut siswa (Putri., dkk., 2010).

Faktor lain yang juga mempengaruhi kebersihan karang gigi pada anak tunagrahita dan tunarungu adalah faktor keluarga walau anak tunagrahita dan tunarungu tinggal bersama orangtua .biasanya mereka diperlakukan secara berlebihan, segala kebutuhannya dibantu sehingga mereka tidak mandiri khususnya 
dalam menjaga kebersihan dan kesehatan gigi dan mulutnya.

\section{Kebutuhan Perawatan periodontal pada Anak Berkebutuhan Khusus}

Hasil penelitian menggambarkan bahwa dari 52 anak berkebutuhan khusus di SLB Dharma Bakti ada 18 (34,61\%) sehat, 1 anak $(1,92 \%)$ memerlukan edukasi instruksi kesehatan mulut (EIKM), 33 anak $(63,46 \%)$ memerlukan edukasi instruksi kesehatan mulut (EIKM) dan instruksi skalling (SK), untuk kondisi poket dangkal dan dalam $0 \%$ tidak memerlukan memerlukan Edukasi instruksi kesehatan mulut (EIKM), instruksi skalling (SK), root planing (RP). Penyebab utama penyakit periodontal adalah iritasi bakteri plak. Plak merupakan suatu deposit lunak yang terdiri atas kumpulan bakteri yang berkembang biak di dalam lapisan suatu matrik intraseluler. Lapisan ini akan mengeras dan melekat erat pada permukaan dan akar gigi bila seseorang mengabaikan kebersihan gigi dan mulutnya. Pembentukan karang gigi dipengaruhi oleh faktor predisposisi yang terdapat secara lokal pada lingkungan rongga mulut atau standar $\mathrm{PH}$ dimana kalkulus yang mempengaruhi kalsifikasi dari karang gigi berhubungan dengan lepasnya perlekatan periodontal pada individu dengan oral hygiene yang rendah (Manson dan Eley,1995). Karang gigi tidak bisa hilang hanya dengan menyikat gigi saja tetapi harus dibersihkan oleh ahlinya baik oleh perawat gigi maupun dokter gigi. Selain dilakukan pembersihan karang gigi juga perlu secara rutin melakukan penyuluhan tentang kesehatan dan kebersihan gigi dan mulut.

\section{KESIMPULAN}

Berdasarkan hasil penelitian maka dapat disimpulkan bahwa kondisi jaringan periodontal persentase tertinggi terdapat pada kategori karang gigi $33(63,46 \%)$ dan 33 anak 63,46\%) membutuhkan perawatan periodontal berupa edukasi instruksi kesehatan mulut (EIKM) dan instruksi skalling (SK).

Kesimpulan tersebut membuat penulis menyarankan agar pelayanan kesehatan untuk anak berkebutuhan khusus perlu dilaksanakan melalui sistem pelayanan kesehatan yang ada seperti UKGS (Unit Kesehatan Gigi Sekolah), puskesmas, dan pelayanan kesehatan lainnya. Pemeriksaan rutin kesehatan disekolah dilakukan sesuai dengan keterbatasan yang anak miliki sehingga dapat diperoleh hasil yang efektif.

Perlu juga diberikan penyuluhan tentang kesehatan gigi dan mulut serta cara pemeliharaan kebersihan gigi dan mulut kepada anak berkebutuhan khusus, guru, serta orangtua. Pada saat guru, maupun dokter dari pihak sekolah memberikan penyuluhan akan lebih baik jika disertai praktik langsung oleh masing-masing anak dan dilakukan secara berulang-ulang, sehingga anak akan lebih mengingat dan dapat melakukannya sendiri.

\section{DAFTAR PUSTAKA}

Haake, Kinder, S., Newman, MG. (2000). Carranza's Clinical Periodontology. 9th ed. Philapelphia: W.B. Sauders Company.

Manson, J.D., Eley, B.M. (1993). Buku Ajar Periodonti . Alih bahasa: Anastasia. EGC Penerbit Buku Kedokteran, Jakarta.

WHO Oral Health Country/Area Profil Programme. Community Periodontal Index 